\title{
The United Kingdom
}

Link to publication record in Manchester Research Explorer

\section{Citation for published version (APA):}

Grimshaw, D., \& Vaughan-Whitehead, D. (Ed.) (2009). The United Kingdom: Developing a progressive minimum wage in a liberal market economy. In The Minimum Wage Revisited in the Enlarged EU Palgrave Macmillan Ltd.

\section{Published in:}

The Minimum Wage Revisited in the Enlarged EU

\section{Citing this paper}

Please note that where the full-text provided on Manchester Research Explorer is the Author Accepted Manuscript or Proof version this may differ from the final Published version. If citing, it is advised that you check and use the publisher's definitive version.

\section{General rights}

Copyright and moral rights for the publications made accessible in the Research Explorer are retained by the authors and/or other copyright owners and it is a condition of accessing publications that users recognise and abide by the legal requirements associated with these rights.

\section{Takedown policy}

If you believe that this document breaches copyright please refer to the University of Manchester's Takedown Procedures [http://man.ac.uk/04Y6Bo] or contact uml.scholarlycommunications@manchester.ac.uk providing relevant details, so we can investigate your claim.

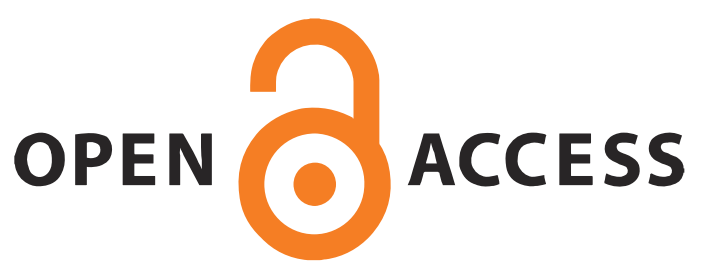




\section{The United Kingdom: Developing a progressive minimum wage in a liberal market economy}

\section{Damian Grimshaw}

\subsection{INTRODUCTION}

The UK Government introduced a statutory national minimum wage in 1999, following two years of consultation and analysis of empirical evidence coordinated by the newly established, tripartite Low Pay Commission (LPC). Prior to 1999 , it was becoming increasingly apparent that a large number of lowpaid workers enjoyed only weak and patchy protection through collective bargaining. The share of all workers covered by collective bargaining had fallen from an estimated 75 per cent in 1980 to just 40 per cent in 1998 (Brown et al., 2003). Moreover, following the abolition of Wages Councils in 1993, for the first time in nearly a century the UK labour market offered no wage floor for the major low paying sectors. In this context, and with the important advantage of a strong labour market performance, the Government was confident that a new statutory minimum wage introduced at an appropriate level would make a positive contribution to fairness - protecting workers from "unacceptably low rates of pay" and forming part of the Government's policies "to make work pay" (DTI, 2006).

The design of the LPC as the body to oversee the introduction, uprating and monitoring of the new minimum wage was a relatively radical step, given the United Kingdom's characterization as a "liberal market economy model" (Hall and Soskice, 2001) During its first ten years, the LPC has proved to be an effective, tripartite institutional arrangement and has established a strong reputation among all social partners. Moreover, each of the ten annual recommendations for the adult minimum rate to date (1999-2008) has been accepted and implemented by the Government.

The past decade therefore provides a valuable country case study for evaluating the impact of a newly introduced national minimum wage in shaping a liberal market economy - especially its effects on low pay, working poverty, employment, job quality and collective bargaining. International studies of 
minimum wages demonstrate that a number of sector- and country-related variables shape the precise nature and extent of minimum wage effects on the labour market (for example, Bazen, 2000; Brosnan, 2003; Card and Krueger, 1995; Kohl and Platzer, 2007). In other words, labour market effects cannot be inferred from a mainstream economics textbook, but instead are contingent on the character of industrial relations, welfare state policies and other labour market institutions associated with a national employment model. In the United Kingdom, the impact of minimum wage upratings on pay structures within firms, for example, is strongly influenced by the weak and patchy collective bargaining coverage. Also, its effect on skill development is shaped by the reputation of national vocational qualifications among employers and workers and the commitment of employers to working with Sector Skills Councils.

This assessment of the UK minimum wage is therefore attentive, as far as possible, to the wider mix of institutional and regulatory arrangements in the United Kingdom. The chapter is structured as follows: Section 14.2 reviews the role of the LPC in fixing the minimum wage, assesses the "bite" of the national minimum wage and considers broader trends in wage structure. Section 14.3 investigates four key labour market outcomes: (i) low pay and working poverty; (ii) wage spillovers and the gender pay gap; (iii) employment (including migrant workers); and (iv) job quality. Section 14.4 presents new data on the relationship with collective bargaining. Drawing on exploratory case studies, Section 14.6 investigates the effects of the national minimum wage on union membership and on trade union pay bargaining strategies and resulting pay structures.

\subsection{THE MINIMUM WAGE: FIXING, RELATIVE LEVEL AND BITE}

Following recommendations from the LPC, the Government introduced adult and "development" national minimum wage rates in 1999. The minimum wage applies to almost all workers who are employed legally in the United Kingdom - including homeworkers, agency workers, part-time workers, casual workers, pieceworkers and migrant workers. Workers not covered include apprentices under 19 years of age and apprentices aged over 19 in the first year of their apprenticeship. It applies to the basic wage, not the total wage, and therefore money paid for overtime, bonuses or shift work cannot be included when calculating the minimum wage. Also, if the employer makes deductions (for example, for transport, uniform or agency fees) then the remaining wage must still meet the minimum rate. The single exception is deductions to cover accommodation (up to $£ 4.30$ per day in 2007-08). 
Table 14.1 Listing of national minimum wage rates, United Kingdom, 1999-2008

\begin{tabular}{lccc}
\hline & Age 22 and over & Age 18-21 & Age 16-17 \\
\hline April 1999 & $£ 3.60$ & $£ 3.00$ & - \\
June 2000 & $£ 3.60$ & $£ 3.20$ & - \\
October 2000 & $£ 3.70$ & $£ 3.20$ & - \\
October 2001 & $£ 4.10$ & $£ 3.50$ & - \\
October 2002 & $£ 4.20$ & $£ 3.60$ & - \\
October 2003 & $£ 4.50$ & $£ 3.80$ & - \\
October 2004 & $£ 4.85$ & $£ 4.10$ & $£ 3.00$ \\
October 2005 & $£ 5.05$ & $£ 4.25$ & $£ 3.00$ \\
October 2006 & $£ 5.35$ & $£ 4.45$ & $£ 3.30$ \\
October 2007 & $£ 5.52$ & $£ 4.60$ & $£ 3.40$ \\
October 2008 & $£ 5.73$ & $£ 4.77$ & $£ 3.53$ \\
\hline
\end{tabular}

Source: LPC reports (2006, 2007, 2008).

Table 14.1 lists the rates. Initially, youths aged under 18 were exempt from the legislation. However, in response to evidence that employers were offering young people jobs at very low wages with no training provision, in 2004 the LPC recommended a new rate for 16-17-year-olds to prevent exploitation.

Members of the LPC include representatives of employers and trade unions, as well as academics. It funds empirical research, listens to oral evidence from a range of organizations, receives several hundred written submissions and undertakes a programme of visits across the country. To date the Commission has published eight reports. In the first, third, fourth and sixth reports, it recommended adult and development rates for two consecutive years, with the proviso that the second year's recommended rate be reviewed in the year prior to its introduction (see LPC, 1998, 2001, 2003, 2005). Since 2007, the Commission has recommended only the rate for that year. The Government has accepted the LPC's recommendations for the adult rate in every year so far. However, it has persistently refused to accept the Commission's view that 21-year-olds be included in the coverage of the adult rate. Moreover, the initial recommended rates for young workers were rejected in favour of lower rates. ${ }^{1}$

There is a dual system for enforcement of the national minimum wage: workers can take their case to an employment tribunal or a civil court, or the

1. In 1999 , the recommended hourly rate of $£ 3.20$ was rejected in favour of $£ 3.00$ and, in June 2000 , the recommended rate of $£ 3.30$ was rejected in favour of $£ 3.20$. Since then, all recommended rates have been accepted by the Government. 
Her Majesty's Revenue and Customs (HMRC) can take action, either by responding to a worker's complaints or proactively investigating a suspect employer following a risk assessment. In 2005-06, 2,100 complaints of underpayment were made to HMRC and HMRC completed around 4,900 investigations into minimum wage underpayment; the incidence of non-compliance detected by investigations was 32 per cent and the value of underpayments was estimated at $£ 3.3$ million (LPC, 2007: 220-21).

\subsubsection{Trends in the relative level of the minimum wage}

The adult rate has increased from an initial $£ 3.60$ in April 1999 to the most recently uprated level of $£ 5.73$ in October 2008. If the increase from April one year to April the next is estimated, in order to align with national earnings data (the Annual Survey of Hours and Earnings, ASHE, available up to 2007 at the time of writing), then the overall rise from April 1999 to April 2007 was 49 per cent, or an annual average increase of 5.1 per cent. This is significantly greater than the rise in average earnings for all employees, which amounted to 37 per cent overall, or an annual average of 4.0 per cent.

In real terms, the minimum wage has clearly increased - although the magnitude depends on the choice of inflation measure (Table 14.2). Using the

Table 14.2 Trends in the minimum wage, United Kingdom, 1999-2007

\begin{tabular}{lrrrrr}
\hline & & & \multicolumn{2}{c}{ Trend change $(1999=100)$} \\
\cline { 4 - 6 } & $\begin{array}{r}\text { Adult } \\
\text { hourly rate }\end{array}$ & $\begin{array}{r}\text { Annual } \\
\text { change } \\
(\%)\end{array}$ & Nominal & $\begin{array}{r}\text { Real } \\
(\mathrm{CPI})\end{array}$ & $\begin{array}{r}\text { Real } \\
(\mathrm{RPI})\end{array}$ \\
\hline 1999 & & & & \\
2000 & $£ 3.60$ & - & 100 & 100 & 100 \\
2001 & $£ 3.60$ & 0.0 & 100 & 99 & 97 \\
2002 & $£ 3.70$ & 2.8 & 103 & 101 & 98 \\
2003 & $£ 4.10$ & 10.8 & 114 & 110 & 107 \\
2004 & $£ 4.20$ & 2.4 & 117 & 112 & 106 \\
2005 & $£ 4.50$ & 7.1 & 125 & 118 & 111 \\
2006 & $£ 4.85$ & 7.8 & 135 & 125 & 116 \\
2007 & $£ 5.05$ & 4.1 & 140 & 127 & 117 \\
Average & $£ 5.35$ & 5.9 & 149 & 132 & 119 \\
annual & & & & & \\
change (\%) & & & & & \\
\hline
\end{tabular}

Note: Author's calculations using price indices as in Figure 14.1. All data refer to April of each year.

Source: LPC website (www.lowpay.gov.uk) and Office for National Statistics (www.statistics.gov.uk) [accessed March 2008]. 
Government's preferred measure, the consumer price index (CPI), the increase in the minimum wage level was 32 per cent during 1999-2007 (3.5 per cent average each year). Applying the retail price index (RPI), which is arguably more realistic since it also includes household mortgage payments, the increase in the minimum wage was rather less - 19 per cent, or 2.3 per cent on average per year.

Overall, the period is characterized by minimum wage growth at a rate above the rise in average earnings and well ahead of price inflation, whichever measure is selected. However, the eight-year period did not witness a consistent approach to the fixing of the minimum wage relative to average earnings (Figure 14.1). During its first two years, the relative level of the minimum wage actually dropped (from 37 per cent to 34 per cent of average pay) due to the cautious stance of the LPC. However, in its reports between 2003 and 2006, the LPC argued explicitly for rises in the minimum wage in excess of projected average earnings growth. This change of stance was a response, in part, to revelations that earnings data used to calculate the initial level of the national minimum wage were flawed. The initial $£ 3.60$ rate was justified at the time by the estimation that it would cover two million workers (Bain, 1999). However, the revised earnings data subsequently showed that only between

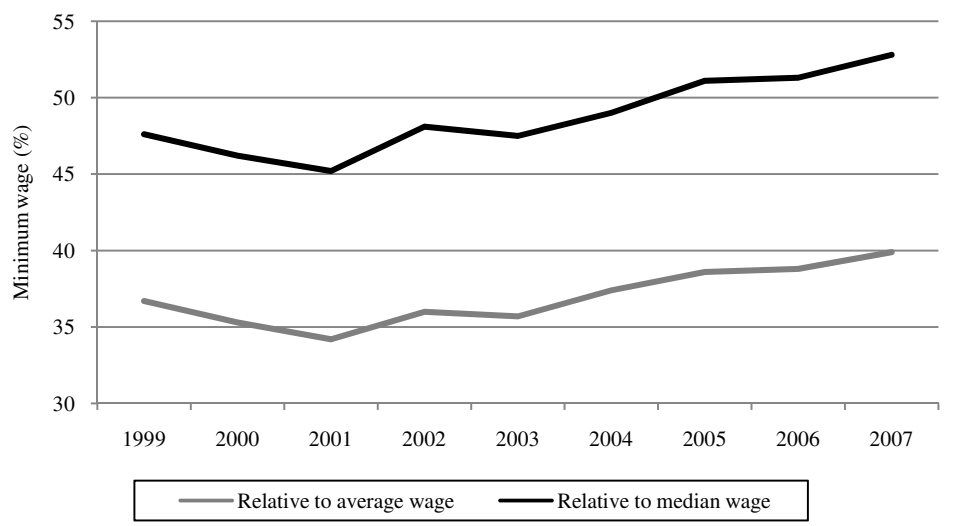

Figure 14.1 Trends in the relative level of the minimum wage, United Kingdom, 1999-2007

Note: Earnings refer to average gross hourly pay for adults, excluding overtime payments. Data for median and average pay cover all full-time and part-time, male and female employees. Minimum wage data refer to April of each year. 
850,000 (Dickens and Manning, 2003) and 1.2 million (LPC, 2003) workers were covered.

Figure 14.1 shows an increase from 36 per cent to 40 per cent of the average wage. Comparing the two periods of minimum wage rises, during the initial "cautious period" (1999-2002) it increased by an average of 4.6 per cent each year and during the "accelerating period" (2003-06) it increased by an average of 6.2 per cent.

At first, all social partners supported an above-average rise in the minimum wage but, in 2005, the CBI called for alignment with average earnings growth. ${ }^{2}$ Combined with greater caution among LPC members about labour market conditions, the LPC again adopted a cautious approach and, in its 2006 report, made the following clear statement:

We do, however, consider that the phase in which the Commission is committed to increases in the minimum wage above average earnings is complete and looking forward, the Commission will start with no presumption that further increases above average earnings are required. ... [The 2003-2006 increases represent] an appropriate upward adjustment from the cautious level at which the minimum wage was originally set, but the Commission has always recognized that the minimum wage cannot increase faster than average earnings indefinitely. (LPC, 2006: vi)

The changing approach of the LPC raises an important question regarding the best way to sustain and improve on the current relative level of the national minimum wage, estimated at 40 per cent of average earnings in 2007. It is clear that, since 2001, low-wage workers have enjoyed six years of steady improvement, thanks to generous hikes in the national minimum wage. However, the reports of the LPC have consistently emphasized that aboveaverage increases are contingent upon labour market performance. At no point has the LPC made a statement about what a suitable level for the national minimum wage might be - whether, for example, 45 per cent or 50 per cent of average earnings might be an appropriate future target, or even whether a negative trend-line in the relative level ought to be avoided. Indeed, the LPC reports eschew any reference to equity or fairness, despite widely reported campaigns by trade unions and living-wage groups (see Grimshaw, 2004), as well as Government efforts to root out poverty among working households through the use of tax credits. In the absence of a benchmark for pay fairness, it is quite possible that even the 2007 level of 40 per cent of average pay,

2. It is notable that, on its website on the national minimum wage, the CBI claims that it was "instrumental" in persuading the LPC to adopt this new position (see http://www.cbi.org.uk/ ndbs/ [accessed November 2007]). 
which is low by international standards (see Chapter 1), may not be sustained during the current downturn in the British economy. Indeed, the new rates for October 2007 and October 2008 point to a likely dampening of the relative level, although it is too early to check actual trends against earnings data. Both the March 2007 and March 2008 LPC reports recommended adult rates below the expected increase in average earnings.

\subsubsection{The bite of the minimum wage}

Simulations of earnings data suggest that between 0.7 and 0.8 million were affected by the 2005 uprating and between 1.1 and 1.2 million by the 2006 uprating (LPC, 2007: tables 2.5 and 2.6). If young employees are also included (aged 16-21), then it is estimated that there were around 1.3 million minimum wage jobs in 2006, representing 1 in 20 of all jobs in the United Kingdom (5.1 per cent) (op. cit.).

Two out of three minimum wage jobs ( 66 per cent) were held by women in April 2006; and nearly half (47 per cent) of all minimum wage jobs were accounted for by women in part-time jobs. Male full-timers accounted for 21 per cent and male part-timers for 13 per cent of all minimum wage jobs (LPC, 2007: figure 2.8). ${ }^{3}$

Coverage of the minimum wage for employees in different age groups follows the three different rates applied to the labour force. In October 2007, the rates were $£ 5.52$ for adults (aged 22 and over), £4.60 for youths aged 18-21 (the "Youth Development Rate", which also applies to those undertaking training) and $£ 3.40$ for employees aged 16-17 years. Coverage by age is broadly U-shaped; the share of minimum wage jobs among employees aged 16-24 years is around 8-10 per cent, but among the 25-59-year-old group it dips to between 4 and 6 per cent and rises to 14 per cent among the 65 and over category (LPC, 2007: figure 2.9). Gender differences vary by age. Among young people (16-21), male employees are overrepresented among minimum wage jobs, but for all adults (22+ years) the share of minimum wage jobs among women is higher than that among men (op. cit.).

The minimum wage also has a disproportionate impact on ethnic minority workers since they are overrepresented in low-paying sectors of employment. An estimated 8.6 per cent of ethnic minority workers were covered by the October 2006 uprating compared to 6.5 per cent of white employees; disaggregated data for ethnic minority groups show that the fraction covered is

3. Minimum wage jobs refer to jobs held by adults aged 22 and over who were paid $£ 5.25$ or less in April 2006, youths aged 18-21 paid $£ 4.40$ or less and youths aged $16-17$ paid $£ 3.25$ or less (see LPC, 2007 for methodology). 
Table 14.3 The bite of the adult minimum wage in low-wage sectors, all employees aged 18 and over, United Kingdom, 2007

\begin{tabular}{|c|c|c|c|c|c|}
\hline & $\begin{array}{r}\text { Median } \\
\text { hourly pay } \\
\text { (SIC code) }\end{array}$ & $\begin{array}{r}\text { NMW } \\
\text { (£5.35) } \\
\text { (as \% of } \\
\text { dian pay) }\end{array}$ & $\begin{array}{r}\text { Paid at } \\
\text { NMW } \\
(\%)\end{array}$ & $\begin{array}{r}\text { Paid below } \\
\text { NMW* } \\
(\%)\end{array}$ & $\begin{array}{r}\text { Total } \\
(\%)\end{array}$ \\
\hline Hospitality & $£ 5.98(\mathrm{H} 55)$ & 89.5 & 16.3 & 13.5 & 29.8 \\
\hline Hairdressing & $£ 6.25$ (O9302) & 85.6 & 8.8 & 17.6 & 26.4 \\
\hline Cleaning & $£ 6.17$ (K747) & 86.7 & 18.9 & 3.0 & 21.9 \\
\hline Leisure, travel and sport & - & - & 6.0 & 7.0 & 13.0 \\
\hline Retail & $£ 6.51$ (G52) & 82.2 & 6.9 & 4.5 & 11.4 \\
\hline Childcare & - & - & 3.8 & 7.3 & 11.1 \\
\hline Textiles and clothing & $£ 7.74(\mathrm{DB})$ & 69.1 & 7.9 & 2.4 & 10.3 \\
\hline Social care & - & - & 4.2 & 2.2 & 6.4 \\
\hline Office work & - & - & 3.3 & 2.8 & 6.1 \\
\hline Agriculture & $£ 7.24$ (A11) & 73.9 & 2.8 & 3.3 & 6.1 \\
\hline Food processing & $£ 8.75$ (DA15) & 61.1 & 4.1 & 0.5 & 4.6 \\
\hline Security & $£ 7.78$ (K746) & 68.8 & 3.4 & 1.1 & 4.5 \\
\hline All sectors & $£ 10.14$ & 52.8 & 2.8 & 2.3 & 5.1 \\
\hline
\end{tabular}

Note: * Employees paid below the national minimum wage include those aged 18-21 paid the development rate, as well as those paid illegally; NMW, national minimum wage.

Source: Pay data from ASHE online earnings data; data on coverage of NMW adapted from LPC (2008: table 2.6).

highest for Asian and Asian British workers, at close to 11 per cent (LPC, 2007: figure 4.19).

Finally, the bite of the minimum wage varies strongly by industry (Table 14.3). In three sectors - hospitality, hairdressing and cleaning - more than one in five employees were paid at or below the adult minimum wage in 2007, rising to as many as 30 per cent in hospitality. Four sectors registered an incidence of more than one in ten workers paid at or below the minimum wage.

\subsubsection{The context of general wage trends}

The introduction and successive upratings of the minimum wage have had a significant impact on the general shape of the wage structure, compressing the bottom end of the distribution and helping to narrow the gender pay gap. Also, improvements in the real level of the minimum wage have occurred in a context of overall growth in real average pay, a continued widening of wage inequality at the top end of the distribution and fluctuations in the wage share of GDP, despite improved productivity since the late 1990s. 
Table 14.4 Trends in the inter-decile measure of wage inequality, United Kingdom, 1997-2007

\begin{tabular}{lccccccccccc}
\hline & 1997 & 1998 & 1999 & 2000 & 2001 & 2002 & 2003 & 2004 & 2005 & 2006 & 2007 \\
\hline D9/D1 & 4.01 & 3.99 & 3.99 & 3.96 & 4.03 & 4.02 & 3.98 & 3.96 & 4.00 & 3.97 & 3.94 \\
D9/median & 2.16 & 2.17 & 2.18 & 2.18 & 2.21 & 2.23 & 2.23 & 2.21 & 2.24 & 2.24 & 2.25 \\
D1/median & 0.54 & 0.54 & 0.55 & 0.55 & 0.55 & 0.55 & 0.56 & 0.56 & 0.56 & 0.56 & 0.57 \\
\hline
\end{tabular}

Note: Average gross hourly earnings, including overtime; author's calculations.

Source: Office for National Statistics, ASHE.

For all employees (full- and part-time, male and female), the average rate of gross hourly pay (excluding overtime) was $£ 13.42$ in April 2007, up by an annual average of 2.6 per cent (CPI) or 1.4 per cent (RPI) in real terms since 1997.4 With the rise in real earnings, together with relatively strong GDP growth, the United Kingdom has witnessed a net rise in the wage share of GDP, according to OECD data, although this rise is less visible from Eurostat data (Chapter 1). However, it is difficult to establish the extent to which the minimum wage has contributed to overall trends. From a low point of 53 per cent in 1996, the wage share increased to 56 per cent in 2001 (that is, the trend increase began well before the introduction of the minimum wage in 1999) and then declined haphazardly to 54 per cent in 2007 (during the period of significant increases in the minimum wage). ${ }^{5}$ It is notable that the 2007 wage share is still lower than that registered in 1985, despite improved productivity and growth in GDP per capita over the 20-year period.

Changes in earnings have been experienced differently at different points of the wage distribution. The 1980s and much of the 1990s in the United Kingdom were characterized by a substantial widening of the wage structure, with the higher paid enjoying most of the fruits of wealth creation in the country. The introduction of the minimum wage in 1999 was, in part, meant to halt, and possibly reverse, this trend. Indeed, the decade since 1997 has witnessed greater stability; the inter-decile (D9/D1) measure has fluctuated around 4.00

4. Data based on author's calculations using price data from the February 2008 edition of Economic and Labour Market Review and wage data from the Annual Survey of Hours and Earnings. Earnings refer to average gross hourly pay, overtime excluded, for all adult employees, which includes male, female, full-time and part-time employees (National Statistics Office - home page at www.statistics.gov.uk; accessed June 2009).

5. Author's calculations using data from the OECD Economic Outlook (2007) database (homepage at http://new.sourceoecd.org/; accessed June 2009). 
with no persuasive evidence of a clear trend (Table 14.4). While the minimum wage may have contributed to a levelling of trends, it is notable that there is, as yet, no evidence of a reversal of the high levels of wage and income inequality that developed during the 1980s and 1990s.

Despite stability in the measure of wage inequality, the internal shape of the wage structure has continued to change. At the top, wages have risen relative to the median, with the highest decile pay rising from 2.16 to 2.25 over the period. And at the bottom, the lowest decile has also increased relative to the median, from 0.54 to 0.57 . More detailed data confirm this picture. During 2000-04, earnings increases up to the 12th percentile were higher on average than the median increase, and so too were earnings increases from the 86th to the 99th percentile (DTI, 2005: figure 2.11).

\subsection{LABOUR MARKET OUTCOMES}

\subsubsection{Impact on low pay and working poverty}

\section{Low pay}

In its first report, the LPC argued that the national minimum wage ought to offset the trend of rising wage inequality, to provide protection against exploitation in low-paying sectors where union representation was low and to improve conditions, particularly for those workers - especially women - most likely to work in low-paid jobs (LPC, 1998). One interpretation of these goals is that the LPC anticipated (at least during the initial period) that the national minimum wage would contribute to a reduction in the share of low-wage work. The evidence in this regard is positive. Adopting a measure of low pay as gross hourly earnings less than two-thirds of the median for all full-time employees, Table 14.5 shows a significant trend decline over the 1998-2007 period by 5 percentage points. The national minimum wage has therefore had a positive impact in reducing the share of low-paid workers.

However, three further aspects of the low-wage data deserve comment. First, it is notable that the bulk of the reduction occurred during 2003-06 when the LPC made a concerted effort to increase the national minimum wage above average earnings increases. The evidence to date therefore suggests that the approach adopted during this period had a direct impact in reducing the share of low-paid; deviation from this approach may be expected to have fewer beneficial effects. Second, the reduction in the share of low-paid work is largely the result of a significant fall in the incidence of low pay among women; men have experienced negligible improvement. Third, despite the 5 percentage point reduction, the absolute level of low-wage work remains very high by international standards (Schmitt et al., 2009). In 2007, 29 per cent - 
Table 14.5 Share of low-paid employees, United Kingdom, 1998-2007 (2/3 of median hourly pay for all full-time employees)

\begin{tabular}{rrrrrrr}
\hline & $\begin{array}{r}\text { Median hourly } \\
\text { pay for all } \\
\text { full-time } \\
\text { employees }\end{array}$ & $\begin{array}{r}\text { Adult } \\
\text { NMW } \\
\text { (April) }\end{array}$ & $\begin{array}{c}\text { Low pay } \\
\text { threshold }\end{array}$ & & \multicolumn{3}{c}{ Percentage low-paid } \\
\cline { 5 - 7 } & & & & All & Male & Female \\
\hline 1998 & $£ 8.16$ & - & $£ 5.44$ & 32 & 22 & 43 \\
1999 & $£ 8.50$ & $£ 3.60$ & $£ 5.67$ & 34 & 23 & 45 \\
2000 & $£ 8.76$ & $£ 3.60$ & $£ 5.84$ & 33 & 22 & 43 \\
2001 & $£ 9.21$ & $£ 3.70$ & $£ 6.14$ & 33 & 23 & 44 \\
2002 & $£ 9.63$ & $£ 4.10$ & $£ 6.42$ & 33 & 23 & 44 \\
2003 & $£ 9.96$ & $£ 4.20$ & $£ 6.64$ & 32 & 22 & 42 \\
2004 & $£ 10.35$ & $£ 4.50$ & $£ 6.90$ & 30 & 21 & 39 \\
2005 & $£ 10.67$ & $£ 4.85$ & $£ 7.11$ & 30 & 22 & 38 \\
2006 & $£ 11.03$ & $£ 5.05$ & $£ 7.35$ & 29 & 22 & 37 \\
2007 & $£ 11.34$ & $£ 5.35$ & $£ 7.56$ & 29 & 21 & 36 \\
\hline
\end{tabular}

Notes: Gross hourly pay for full-time and part-time employees, aged $22+$ and excluding overtime and other bonuses; 1998-2003 data are partly based on LFS data; author's estimates of percentages of low-paid are accurate only to the nearest 1 percentage point; NMW, national minimum wage.

Source: All years based on ASHE data. 1998-2003 estimates from the Office for National Statistics (www.statistics.gov.uk/downloads/theme_labour/ASHE_1998_2004/Table1.xls); 2004-07 author's calculations of low pay derived from inter-decile earnings distribution.

close to one in three - of all adult employees (aged 22 and over) were lowpaid. Among women, the figure was 36 per cent. 6

Low-paid workers are concentrated in particular sectors. Nine out of ten low-paid workers are employed in just four sectors: retail (46 per cent of all low-paid workers), hospitality (hotels and restaurants, 29 per cent), residential social care (7 per cent) and cleaning ( 7 per cent); other low-paying sectors include agriculture, hairdressing, security and textiles, clothing and footwear (DTI, 2005: figure 3.1). In terms of the relative risk of low pay, it is approximately 70 per cent in hotels and restaurants and more than 30 per cent in wholesale and retail, agriculture and other social and personal services (Cooke and Lawton, 2008: figure 2.6).

\section{Working poverty}

A minimum wage can have three possible effects on the incidence of poverty among households with working age adults (Sutherland, 2001): (i) a direct

6. A key reason for women's higher share is their concentration in low-paid part-time jobs. Note that the low-wage data cited in Mason et al. (2008) refer to a benchmark of two-thirds of earnings of all employees, rather than full-time employees, as used in this chapter. 
effect by increasing earnings through paid work; (ii) an indirect effect by making paid work more attractive and thereby reducing problems related to the unemployment trap; and (iii) a combined direct and indirect effect through the operation of associated welfare policy measures that provide in-work benefits (Working Tax Credits in the United Kingdom) (Brewer et al., 2007; Sutherland et al., 2003).

The UK Government considers the national minimum wage to be not only an instrument for providing a floor to wages, but also as a tool to combat working poverty alongside Working Tax Credits. The need to target low-wage workers is amply supported by data on poverty risk. Using 2004-05 data, Cooke and Lawton (2008: 42) estimate that 7.2 per cent of low-wage workers live in poor households, compared to 1.9 per cent of all working adults. And the risk of poverty among low-wage part-time workers was double (10 per cent) that of the risk among low-wage full-time workers ( 5 per cent) (2008: 45).

So, has the national minimum wage been an effective instrument against inwork poverty? One early simulation estimated that the national minimum wage had only a marginal impact among single-earner poor households, but a more significant impact among dual-earner households, with reductions in the poverty rate of 2.7 per cent and 12.1 per cent, respectively (Sutherland, 2001: table 3). A more recent study using 2006 data finds that the national minimum wage has lifted only a small subset of household types out of poverty (Cooke and Lawton, 2008). These include single-adult households, dual-earner childless households (where both work full-time, or a mix of full-time and parttime) and dual full-time earner households with one or two children under 11 years old. ${ }^{7}$ Other household types require a far higher minimum hourly wage to escape poverty. For example, estimates suggest that single-earner couple households without children require an hourly wage of $£ 7.69$ (for a full-time job) or $£ 16.88$ (part-time) to escape poverty, or alternatively must work 53 hours per week (Cooke and Lawton, 2008).

One of the flaws in the Government's anti-poverty approach has been to attempt to marry an individual right to a statutory minimum wage with a household-based entitlement to means-tested welfare benefits and Working Tax Credits. This system discriminates against second earners, who are predominantly women, and distorts the impact of the minimum wage. In response, the Institute for Public Policy Research recently called for a new "Personal Tax Credit Allowance". In written evidence to the Treasury Select Committee, the Institute for Public Policy Policy Research (IPPR) argues that

7. However, the estimates for households with young children are undermined by the fact that the model assumes no childcare costs. 
such an allowance would have the effect of increasing the minimum earnings threshold for each adult before entitlement to tax credits start to be withdrawn, thus making it more attractive for both partners in a dual-earner household to work and increasing net weekly earnings considerably. ${ }^{8}$

\subsubsection{Impact on wage spillovers and the gender pay gap}

\section{Wage spillovers}

A common concern for governments when introducing or uprating the minimum wage rate is to understand the knock-on impact on wage rates further up the wage distribution - the wage spillover effect. Where wage differentials are fully restored, the redistributive impact of the minimum wage is subverted and the relative level of the minimum wage remains the same. Moreover, restoration of differentials may generate inflation, leading to a loss of competitiveness. However, in the absence of any wage spillover effect, the wage structure will be compressed around the wage floor set by the minimum wage, generating a strong segmentation of jobs paid at or just above the minimum.

For the United Kingdom, the evidence suggests that wage differentials have generally not been restored following the introduction and successive upratings of the minimum wage. Surveys suggest that many firms are using the minimum wage, not as a floor for pay rates, but as the going rate for many occupations (IDS, 2004). ${ }^{9}$ Another IDS survey (2007) shows a narrowing of pay differentials between team members and supervisors in many fast food outlets, pubs and restaurants. Similarly, a detailed study of 25 firms in the hospitality, retail and personal services sectors found that 11 firms did not restore differentials among all workers following the 2005 minimum wage uprating (Denvir and Loukas, 2007). ${ }^{10}$ Instead, employers eliminated pay scales for low-paid jobs and introduced single spot rates; for example, the Co-operative supermarket chain consolidated the four pay rates for non-supervisory sales staff into a single rate (from a range of $£ 4.53$ to $£ 4.85$ in $2003-04$ to a single flat rate of $£ 5.00$ for 2004-05) (Denvir and Loukas, 2007).

8. See the press release at www.ippr.org/pressreleases/?id=2965 (accessed June 2009).

9. For example, the median starting rate for a nursery assistant in 2001 and again in 2003 was the exact equivalent of the minimum wage ( $£ 4.10$ in 2001 and $£ 4.50$ in 2003). Three-quarters of pubs and restaurants surveyed paid new recruits the minimum wage. Also, at half of the hotels surveyed in 2003, the starting rate was the minimum wage (IDS, 2004).

10. Unfortunately the survey does not distinguish between pay differentials among non-managerial staff and pay differentials among non-managerial and managerial staff; had the question been limited to non-managerial staff it is possible the number of firms not restoring differentials would have been higher. The report also does not include data on pay rates in each of the case study firms. 
Two factors explain the compression and lack of restoration of wage differentials at the bottom of the wage structure. The first factor is the absence of an inclusive system of collective bargaining. In most UK workplaces, pay is set unilaterally by managers and most workers are not union members; 2006 data suggest union density of 28 per cent and collective bargaining coverage of 34 per cent (Grainger and Crowther, 2007). In the absence of joint regulation over pay, workers have weaker bargaining power to negotiate a pay rise with their manager and are therefore more likely to experience erosion of pay differentials with lower-paid colleagues. The second factor relates to in-work benefits (Working Tax Credits) and other means-tested welfare payments made to lowwage workers. Where an employee receives tax credits and housing benefits, the employer may be disinclined to increase pay in response to rising living costs. Moreover, the employee has weak incentives to bargain for higher pay in a situation where higher pay substitutes, pound for pound, with reduced benefits.

Overall, there is a risk that the UK labour market is developing a strong line of segmentation between a minimum-wage labour market and a decent-wage labour market, as already suggested by a growing spike in the wage distribution at around the minimum wage in many sectors (see Table 14.3 above, and Low Pay Commission, 2008: figure 2.8).

\section{The gender pay gap}

It is widely accepted that progressive policy action to reduce the share of the low-paid can have a positive impact on narrowing the gender pay gap, due to women's overrepresentation among the low-paid (two-thirds of the jobs affected by the October 2007 national minimum wage uprating were held by women). However, the beneficial effect obviously depends on the relative and absolute level at which it is set and most commentators now agree that it was initially pitched at far too low a level to make a significant immediate impact. Over the medium term, the evidence is more positive thanks to increases above average earnings growth during 2003-06.

Studies of the impact of the introduction and initial upratings of the national minimum wage on the gender pay gap suggest that its effect was limited. Robinson's (2002) study found that it had only "a moderate effect" precisely because it was set at too low a level. While the overall distribution curve for women's wages did shift slightly to the right, the location of the peak (mode) of the curve did not change significantly from 1998 to 1999, so that "for many low-paid women, the introduction of the NMW had little impact" (Robinson, 2002: 431). Robinson's simulations show that a slightly higher level would have made a significant difference: an initial level of $£ 3.70$ instead of $£ 3.60$ would have improved the gender pay ratio from 73.7 per cent to 74.3 per cent in 1999. 
Since this early evaluation, direct evidence compiled from earnings data (ASHE database, Office for National Statistics) suggests that the above-average earnings rises in the national minimum wage have had a positive impact on women's relative pay. While the median pay gap closed only fractionally between 1997 and 2002 (a result which fits with Robinson's analysis), the subsequent period saw a larger improvement in women's relative pay. Among female full-timers relative pay increased from 85 to 88 per cent during 2002-07, and among female part-timers it increased from 56 to 61 per cent. Improvements in women's relative pay at the lowest decile (D1) follow a similar pattern. There was relatively little change during 1997-2002 but, thereafter, a rise from 89 to 92 per cent for female full-time employees and from 74 to 81 per cent for female part-time employees. One cause for concern, however, is the low level of pay for women in part-time jobs. At just over 60 per cent of male full-timers' median pay, there is a clear need to address the problem of women's part-time work, which is concentrated in low-wage segments of the economy.

\subsubsection{Impact on employment}

The national minimum wage was introduced in the United Kingdom at a time of relatively strong economic growth, with growth rates at or above the OECD average in both 1998-2004 and 2007 (OECD, 2007). It was expected that its introduction would increase the labour supply, as more people found it attractive to enter paid employment. However, several other structural changes also increased the labour supply, raising questions about the ability of the labour market to absorb increases in wages without generating unemployment. These changes include an increase in migrant workers (especially from Eastern Europe following the $2004 \mathrm{EU}$ enlargement), students (who need to finance newly introduced university fees), people registered as sick or disabled (in response to more restrictive welfare reforms), lone parents and people over pension age (especially women).

Despite the increased labour supply, the UK labour market has adapted to the regulated wage floor and, until the 2008 slowdown, managed to sustain positive job growth. Employment has risen, year on year, since the introduction of the minimum wage in 1999, reaching 29.4 million by the last quarter of 2007. The trend line suggests that the rate of employment growth evident during the four years preceding the introduction of the national minimum wage continued at a similar level post-1999. Also, unemployment has generally declined, with the exception of a sluggish period between mid-2005 and mid-2006. The rise in numbers employed has, of course, had to keep pace with population growth and here the evidence suggests a less strong, albeit still positive, performance. The employment rate for the population aged 16-59 
(women) and 16-65 (men) increased from 73.2 per cent in 1998 to 74.9 per cent in 2008 (January-March data, Office for National Statistics). Among the core age group, 35-49 years, the employment rate increased from 80.6 per cent in 1998 to 82.5 per cent in 2008.

Even among low-paying sectors, the number of jobs has grown during the period of minimum wage introduction and development. Between December 1998 and September 2007, there was a net increase of more than 600,000 jobs, compared to an increase of more than 2 million across all sectors (LPC, 2008). The low-paying sectors with highest job growth during 1998-2007 were retail (more than 300,000 jobs) and hospitality (around 250,000) (op. cit.: table 2.8). However, some low-paying sectors have witnessed a decline in jobs - cleaning, agriculture, food processing and, most notably, textiles and clothing, resulting in the loss of around 200,000 jobs since 1998.

More detailed econometric studies (Stewart, 2002, 2004) show no significant impact of the introduction and upratings of the national minimum wage on employment for the separate groups of men, women, adults or young workers. For example, Stewart's (2004) study estimates the impact of the 1999 introduction and the subsequent upratings of 2000 and 2001 on the probability of employment among employees whose pay would have to be raised to comply with the legislation. In Stewart's words, "no significant adverse effect is found" for the different demographic groups examined (Stewart, 2004: C116). Other studies that focus on a particular low-paying sector have found minor adverse effects. Machin and Wilson's (2004) survey data from the carehome sector show negative employment effects, although "these are modest in magnitude and often on the fringes of statistical significance", especially given the magnitude of the wage effects following the introduction and upratings of the minimum wage (Machin and Wilson, 2004: C109). ${ }^{11}$

\section{Migrant work}

The United Kingdom has witnessed a substantial increase in migrant workers, especially since 2004. Migrant workers are a heterogeneous group with a variety of both high and low employment rates and high and low unemployment rates, contingent largely on skill and country of origin (LSC, 2007: 9). Recent research has focused on the impact of migrant workers from the A8 countries (those countries that joined the EU in 2004, but excluding Cyprus and Malta,

11. Another concern regarding the impact of a minimum wage on employment is that it fuels selfemployment as a means of bypassing the regulations. However, in the United Kingdom this situation has not arisen. Comparing 1998 with 2007, the number of self-employed in low-paying sectors fell by 6 per cent, while self-employment in the whole economy grew by 10 per cent (LPC, 2008: 39). 
whose nationals have free movement of labour) who can work in the United Kingdom, provided that they register with the Worker Registration Scheme (WRS). WRS data (worker inflows only) show that 715,000 A8 nationals were registered for work between May 2004 and September 2007.

In terms of their overall effect on employment, the evidence to date suggests that migrant workers are being employed in hard-to-fill jobs rather than substituting for British workers. While the employment rate of A8 migrants has increased significantly in recent years (from less than 60 per cent in summer 2003 to more than 75 per cent in summer 2005), there has been no compensating fall in the employment rate, either among the UK-born population or the non-A8 migrant population (Gilpin et al., 2006: figure 5.1). More detailed analysis at regional level (including a restricted analysis of regions where migration has been highest) also finds no statistically significant impact of A8 migration on claimant count unemployment (Lemos and Portes, 2008: chart 3 ). Thus, the increased labour supply does appear to have been absorbed in the context of a rising minimum wage.

One important impact of this recent wave of immigration has been to increase the overrepresentation of migrant workers in low-paying sectors. The LPC estimates that 70 per cent of all workers registered from the A8 countries were employed in ten low-paying occupations, including factory operatives (27 per cent), packers or warehouse operatives (14 per cent), catering workers (6 per cent), cleaners (6 per cent) and farm workers (4 per cent) (LPC, 2008: figure 3.11, author's calculations). Gilpin et al. (2006) show that most A8 workers have been filling low-skill job vacancies and Lemos and Portes (2008: chart 3) find that the wages earned are relatively low; 72 per cent of those registered with the WRS earned between $£ 4.50$ and $£ 6.00$ in 2007 (when the adult national minimum wage was $£ 4.85$ ), compared to a little over 10 per cent of UK workers. It is perhaps no surprise, then, that anecdotal evidence during 2005 and 2006 suggested that migrants were taking jobs away from the low-skilled. Again, however, the econometric evidence does not support this premise; modelling the impact on the less skilled, women and young workers finds that the impact on claimant count unemployment is almost always insignificant (Lemos and Portes, 2008).

One area which gives cause for concern relates to non-compliance with the national minimum wage. The Government carries out monthly checks on up to 15 employers of migrant workers on the basis of information from the Worker Registration Scheme. During 2005-07, more than one in four employers investigated were found to be non-compliant, with arrears owing to nearly 3,000 workers (LPC, 2008: 116). Compliance among gangmasters is monitored by the Gangmasters Licensing Authority (GLA), which was set up in 2005 in response to the death of 23 Chinese cockle pickers. Around 1,200 gangmasters are registered with the GLA. Operating without a license is an 
offence, carrying a ten-year prison sentence. Since the GLA was established, more than 50 gangmasters have had their licenses revoked. For example, in May 2008 the GLA barred one of the largest UK gangmasters from supplying migrant workers to harvest daffodils after finding evidence of forced labour including failure to provide adequate housing, paying as little as $£ 24$ a day and imposing debts on the, mainly Polish, workforce. In its report, the GLA stated: "These vulnerable workers were threatened with huge deductions from wages and there was an even more sinister threat to involve their families in their home country if they left the employment of the gangmaster or failed to pay money to him. Abhorrent working and living conditions meant the workers were housed in sub-standard accommodation and transported in prohibited, uncertified vehicles" (Lewis, 2008).

\subsubsection{Impact on job quality}

An important potential effect of a minimum wage is its ability to transform the quality of jobs through an incremental upgrading of performance among firms in low-paying sectors. The LPC has repeatedly referred to the anticipated role of the national minimum wage in improving job quality by: "encouraging firms to compete on the basis of quality as well as price; helping to promote employee commitment, reduce staff turnover and encourage investment in training, thereby boosting productivity and aiding company competitiveness" (LPC, 1998: 15).

However, in the United Kingdom such expectations have proved elusive. The combined findings from many studies on the direct and indirect effects of the minimum wage on job quality suggest at best only a marginal positive effect. Moreover, there has been no discernible impact of the national minimum wage on UK productivity (Forth and O'Mahony, 2003; LPC, 2003: 56-7). Research studies demonstrate that employers adopt a broad-ranging approach when seeking to minimize costs and are not solely concerned with job cuts in response to the minimum wage. Nevertheless, when organizations' responses are classified as high road or low road (sometimes referred to as "quality enhancing" or "cost minimising"), the evidence suggests that the latter route predominates. ${ }^{12}$

One reason is that, while legal pressure to pay higher wages has encouraged some firms to improve the quality of their product or service or to switch to niche-based product markets, it is not obvious that this represents a "high road", sustainable form of work organization. Improved product or service quality may reflect positive changes such as investment in new technologies

12. For example, in the survey by Heyes and Gray (2003) 61 per cent of small firms seeking to offset costs reported work intensification. 
and a strengthened commitment to human resource management (HRM) practices. Equally, however, it may bring negative changes such as work intensification $^{13}$ and minimal improvements in traditional production processes (Bullock et al., 2001; Heyes and Gray, 2003; Ram et al., 2001).

A second area of ambiguity concerns the impact of the national minimum wage on training. While some firms have improved the quantity and quality of training provision in response to the national minimum wage, the bulk of firms surveyed reported no change (Arulampalam et al., 2002; Heyes and Gray, 2003; Miller et al., 2002). More recently, Dickerson's (2007) analysis using the Labour Force Survey found no evidence that employers had responded to the minimum wage by either increasing or reducing the volume of training provided at the workplace. A possible cause relates to the United Kingdom's well-documented problems with vocational training. A case survey of 36 lowpaying small firms (Grimshaw and Carroll, 2006) shows that even those firms operating in quality-led, niche markets were reluctant to provide employees with certified training owing to disillusionment and poor past experience with National Vocational Qualifications.

A final missing link in the chain connecting the minimum wage with other improvements in job quality relates to the currently underdeveloped role of local, or sector-based, associations. Edwards et al. (2002) show that business and trade associations can assist in the pooling of small firms' knowledge and the diffusion of formal and informal rules, especially to improve technical standards, expertise in contracting and approaches to skill development and training.

In general, research suggests that broad-ranging policy reforms are required to encourage enhanced job quality in a manner that recognizes the particularities of sectoral product market conditions and labour market institutions.

\subsection{THE IMPACT ON COLLECTIVE BARGAINING}

One issue that has received little attention in analyses of the impact of the national minimum wage on the UK labour market is its effect on collective bargaining. This is surprising given the rather turbulent history of low-wage

13. For example, in preparation for the introduction of the national minimum wage, 55 per cent of hotels surveyed expected to adopt a cost minimising approach (for example, by employing more young staff, cutting training and reducing overtime premia) and only one-third to implement a "high road" approach (for example, employing more older staff and increasing training) (Brown and Crossman, 2000). Similarly, in Bullock et al. (2001), low road responses such as increased labour turnover were more common than high road responses such as increased training provision. 
protection in the United Kingdom and the debates surrounding the proper role of legislation in a voluntarist system of industrial relations.

The first legislation enacted to protect the low-paid was the introduction of Trade Boards in 1909 to set minimum wages, enforceable under criminal law, but restricted to the so-called "sweated trades". Initially, four sectors were covered - tailoring, paper-box making, machine-made lace and chain-making (Dobb, 1944). Coverage was gradually expanded and Boards were renamed Wages Councils. By 1962, there were 60 Councils covering 3.5 million workers. The overall rationale of Wages Councils was intended to be in keeping with the United Kingdom's approach to industrial relations, with the goal being "to supplement and not to supplant the voluntary system of regulation" (Rubery and Edwards, 2003: 454). Nevertheless, from the late 1960s trade unions became increasingly opposed to them. This reflected a "traditional" union view that legislation on wage setting would necessarily hinder free collective bargaining (Bain, 1999), a reflection of the union movement's historical antipathy to any state involvement in the realm of industrial relations. Thus while in 1970 the Trades Union Congress (TUC - the peak organization for the British trade union movement) produced a report entitled "Low Pay", it called only for a voluntary national minimum wage. Indeed, Blackburn writes that, during the late 1970s, "the unions were probably more vociferous in their condemnation of the councils than any other group in society" (1988: 131). Union complaints included the relative infrequency of pay settlements and the low pay awards compared to workers covered by collective bargaining.

However, it was a Government with quite a different ideological approach - the Thatcher Government, with its adherence to free markets - that rejected Wages Councils, first curtailing their powers in 1986 and finally abolishing them entirely in 1993 (Kessler and Bayliss, 1998). The highly charged political battleground of the 1980s and early 1990s, combined with a rapid rise in wage inequality and in the numbers of low-wage workers, shifted the balance of long-running debates within British trade unions on the merits of legal regulation to supplement voluntary collective bargaining. Unions saw that in those sectors where Wages Councils had their powers restricted and eventually abolished, collective bargaining had not flourished and wages had fallen further (Machin and Manning, 1994; Cox, 1994). In 1986, for the first time the TUC adopted a resolution in favour of a statutory minimum wage. This was welcomed by many unions, especially NUPE, the public sector union (now part of Unison, see below), which, under the leadership of Rodney Bickerstaffe, had campaigned alone for a minimum wage for some 20 years, but opposed by others such as the Transport and General Workers' Union (TGWU), which argued that a legally enforceable minimum was a stepping stone to a rigid incomes policy (Blackburn, 1988). 
Table 14.6 Trade union recommendations to the Low Pay Commission Report, United Kingdom, 2008

\begin{tabular}{|c|c|c|c|c|c|}
\hline \multirow[t]{2}{*}{ Union } & \multirow[t]{2}{*}{ Membership } & \multirow{2}{*}{$\begin{array}{l}\text { Written } \\
\text { evidence } \\
\text { to LPC? }\end{array}$} & \multicolumn{3}{|c|}{ Union recommendations to the LPC: } \\
\hline & & & $\begin{array}{l}\text { Adult rate } \\
\text { (LPC actual } \\
\text { rate } £ 5.73 \text { ) }\end{array}$ & $\begin{array}{l}\text { Adult age } \\
\text { range (actual } \\
\text { range } 22+\text { ) }\end{array}$ & Other \\
\hline CWU & 241000 & yes & $?$ & $16+$ & \\
\hline GMB & 576000 & & $£ 7.00$ & & \\
\hline PCS & 311000 & yes & $£ 8.00$ & $18+$ & $\begin{array}{l}\text { Should not consider } \\
\text { regionalization (excep } \\
\text { London) }\end{array}$ \\
\hline Unison & 1343000 & yes & $£ 6.75$ & $16+$ & $\begin{array}{l}\text { Should not consider } \\
\text { regionalization }\end{array}$ \\
\hline Unite & 1942000 & yes & $£ 6.00$ & $18+$ & $\begin{array}{l}\text { Close gap with } \\
\text { youth rate }(16-17) \\
\text { Should not consider } \\
\text { regional rates } \\
\text { Increase penalty } \\
\text { for non-compliance }\end{array}$ \\
\hline Usdaw & 341000 & yes & $£ 6.00$ & $18+$ & $\begin{array}{l}\text { Youth rate at } 80 \% \\
\text { of adult rate } \\
\text { Rule out indexation } \\
\text { linked to } \\
\text { productivity } \\
\text { or median pay }\end{array}$ \\
\hline TUC & $\begin{array}{c}\text { Peak } \\
\text { association }\end{array}$ & yes & $£ 6.00$ & $18+$ & $\begin{array}{l}\text { Increase penalty } \\
\text { for non-compliance }\end{array}$ \\
\hline
\end{tabular}

Source: LPC website, union websites plus www.personneltoday.com (accessed June 2008).

Today, all major trade unions support the national minimum wage and the larger unions regularly submit evidence to the LPC. Table 14.6 documents the written and oral recommendations of the largest unions, as well as the TUC, submitted in time for the 2008 LPC Report. All unions expressed dissatisfaction with the adult hourly rate of $£ 5.52$ as of October 2007 , and argued for a significant increase for October 2008. This ranged from a figure of $£ 6.00$ (Unite, Usdaw and the TUC) to $£ 8.00$ (PCS). The eventual figure recommended by the LPC (and accepted by the Government) was £5.73. Furthermore, all unions that submitted written evidence to the LPC argued for some form of consolidation of the youth rate into the adult rate. The adult rate applies to persons aged 22 and over. Unions instead argued for the adult rate to apply either to persons aged 16 and above (CWU, Unison) or, more commonly, and above (PCS, Unite, Usdaw and TUC). Other issues voiced by unions include an increase in the penalty for non-compliance and the rejection of LPC proposals to consider a regional minimum wage. 
It is interesting to consider the reasons for the discrepancies in recommended rates among these large unions. Why do some unions, such as the PCS, recommend a minimum of $£ 8.00$, but others just $£ 6.00$ ? Are some unions more cautious because of the risk of undermining incentives to attract new members to the union - especially the union promise to bargain for a fair wage? In a related context, are some unions concerned that the minimum wage might catch up with minimum rates set in collective bargaining agreements? The following case studies consider these issues through the lens of two of the largest collective bargaining agreements in the United Kingdom. The results derive from original interview data with senior union officials, as well as secondary data kindly provided by the two trade unions.

\subsection{CASE STUDIES: MINIMUM WAGE INFLUENCE ON COLLECTIVE AGREEMENTS IN RETAIL AND HEALTH SERVICES}

Two collective bargaining agreements were selected on the basis of their size and importance for the UK workforce, as well as their relevance for low-wage work. The first agreement is in the retail and distribution sector. It is a singlecompany, single-union agreement between Tesco, the United Kingdom's largest supermarket chain, and Usdaw, the principle union for retail workers. Covering 139,000 workers, this "Partnership Agreement" is in fact the largest private sector agreement in the United Kingdom. Describing the nature of the partnership, a senior union official interviewed said, "There is nothing cushy or compliant about our relationship with Tesco. It is a hard slog and takes up a lot of time and energy and resources."

The second agreement is in the public sector. It is a national agreement between a number of trade unions and professional associations and the National Health Service Employers' Federation. Known as "Agenda for Change", and covering some 1.3 million workers, it is the largest jointly negotiated agreement in the United Kingdom. The focus of the case study is Unison, since it represents a high share of low-wage workers. Unison is the largest trade union for workers (employed by both the public and private sectors) delivering public services. Box 14.1 provides some background on the two agreements.

In both case studies, two research questions informed the data collection and analysis:

(1) What are the effects of the national minimum wage on union membership?

(2) What are the effects of the national minimum wage on union pay bargaining strategies and resulting pay structures? 
Box 1: Overview of two collective bargaining agreements

\section{The Usdaw-Tesco "Partnership Agreement"}

Launched in 1998, this Partnership Agreement covers 139,000 workers (approximately 50 per cent density - 2008 data) and is the largest private sector agreement in the UK. Usdaw is the sole union recognized by Tesco for the purpose of representing and negotiating for Tesco staff. The agreement applies to all Tesco staff (union and non-union members) except managers above Section Manager level. It is reviewed and negotiated annually and contains agreements on pay, pay premia and bonuses, as well as all other major areas of employment policy and practice, including grievance and disciplinary procedures, use of employment contracts, working time (entitlement to breaks and annual leave) and sick pay.

A distinctive feature of the partnership is the strong participatory framework for Usdaw local union representatives. Representatives are elected for all Tesco stores and they have clearly defined responsibilities at local, regional and national forums. The partnership agreement provides time off for union representatives to attend meetings and training outside the store.

\section{Unison and the National Health Service "Agenda for Change"}

This collective bargaining agreement applies to all employees working in the National Health Service (the UK public health care sector), except doctors, dentists and some senior managers. It is relatively new (replacing 12 previous separate occupational collective agreements) and involves negotiations between multiple trade unions and professional associations with the NHS employers' body. Unions played a strong role in setting the three core objectives of this new agreement, namely: to harmonize terms and conditions across occupations; to improve pay for the lowest paid; and to provide better pay and promotion prospects for all workers. A new job evaluation, combined with a framework for developing skills and knowledge, is expected to contribute towards fulfilling these goals.

Of the various unions party to the pay agreement, Unison is the largest. It represents workers across the full range of public services. In healthcare, Unison claims more than 400,000 members, including NHS employed staff, as well as employees working for private contractors or in the voluntary sector. Members are from a range of occupations, including ancillary, administrative and maintenance, as well as nursing and allied professionals. Along with the GMB, Unison is the union most representative of low-wage workers in the NHS. It has played an important role in defining the core objectives of "Agenda for Change" and in negotiating pay deals, including the latest three-year deal, which included a significant boost for low-wage workers. 


\subsubsection{Effects on union membership}

For the United Kingdom as a whole, there is no evidence of an obvious negative effect of the national minimum wage on union membership. Figure 14.2 plots trend changes in the real level of the national minimum wage, adjusted for the RPI, and in the levels of union density in the public and private sectors. Since the introduction of the national minimum wage in 1999, union density in the private sector has decreased (by 14 per cent) as the real value of the national minimum wage has increased (by 17 per cent). However, the decline in private sector union density represents a clear continuation of a pre-1999 trend, and the introduction of the national minimum wage is not associated with an increase in the rate of decline. Moreover, union density in the public sector has remained relatively stable throughout the period, suggesting again that there is no evidence of an adverse national minimum wage effect on membership. Thus, while there are clear challenges facing trade unions, especially in the private sector where density levels dropped from 21.6 per cent in 1995 to 16.6 per cent in 2006 , there appears to be no reason for unions to identify the rising national minimum wage as a causal factor.

Evidence from the two case studies supports this general conclusion. The 1980s debate among unions about the potential for legal intervention to hinder

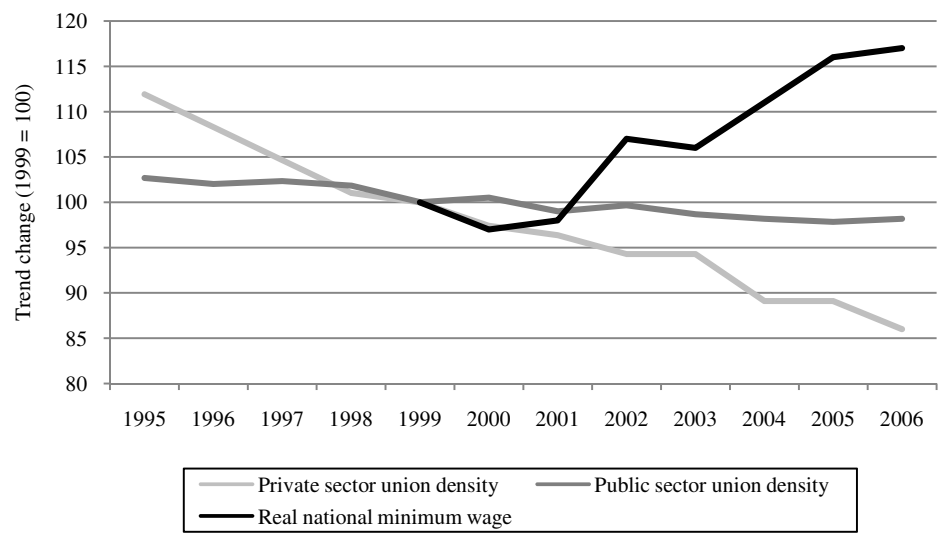

Figure 14.2 Trend changes in the real level of the national minimum wage and public and private sector union density, United Kingdom, 1995-2006 $(1999=100)$

Source: Trade union data from Grainger and Crowther (2007); trend change in real minimum wage (RPI adjusted) from Table 14.2 above. 


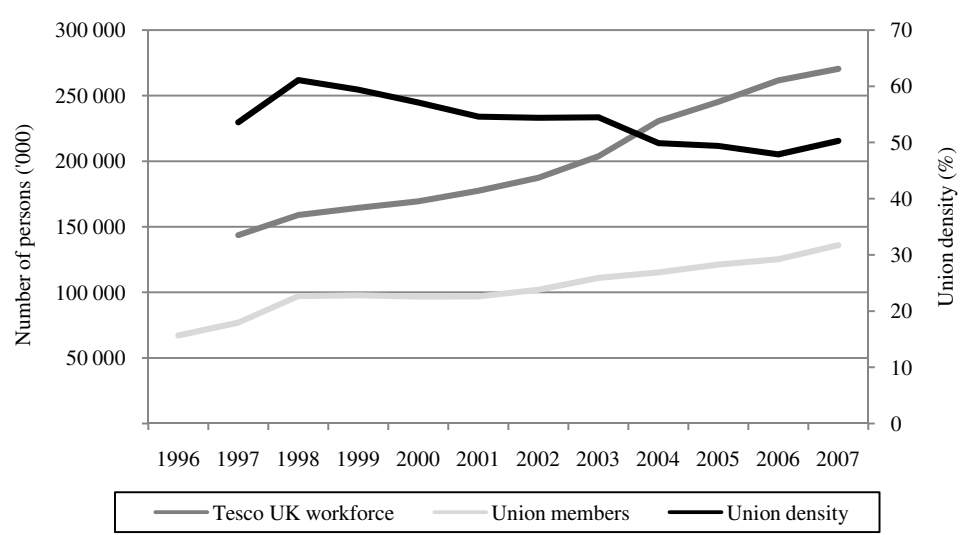

Figure 14.3 Usdaw union membership among Tesco employees, United Kingdom, 1996-2007

mobilization efforts (with, for example, the TGWU arguing for a voluntarist approach and NUPE arguing for intervention to protect the low-paid) has disappeared. Unison was established through a merger that involved NUPE and closely follows the NUPE tradition of promoting the national minimum wage. The interviewed senior official from Unison did not identify a significant national minimum wage effect on Unison's ability to recruit new members. Usdaw has enjoyed a steady rise in union membership across the Tesco stores. However, because of the very rapid expansion of the Tesco workforce (a near doubling in the past decade), union density has dropped - from a high of 61 per cent in 1998 to just over 50 per cent (following a recent rise) in 2007 (Figure 14.3). Again, therefore, it is not possible to identify an obvious adverse national minimum wage effect on membership. Usdaw continues to attract new members on the basis of its success in strengthening representation at the workplace, in defending workers involved in disciplinary and grievance cases (especially regarding current Tesco practices of attendance management) and in having negotiated adult and youth rates of pay considerably higher than the national minimum wage rates.

\subsubsection{Effects on pay structures}

In both cases, the increase in the real value of the national minimum wage since 2000 has had a positive, upgrading effect on pay scales negotiated through collective bargaining. The details of each case are considered separately below. 


\section{The Usdaw-Tesco Partnership Agreement}

The national minimum wage has had a moderate effect on improving bottom rates of pay at Tesco. By forcing other retailers with weak or no union representation to improve pay, Usdaw identified a narrowing of the gap in starter rates of pay between Tesco and its competitors. It successfully persuaded Tesco that it made good business sense to maintain a pay differential with its competitors to attract good quality recruits and retain workers. According to the two officials interviewed, the Partnership Agreement establishes as an "implicit guiding principle" that, as the number one retailer, Tesco ought to commit to being number one in terms and conditions (pay, as well as pensions and customer discounts). For Usdaw, this is part of improving the overall attractiveness of retail jobs at Tesco and "saying that retail is a real job and ought to be attractive to people who want to come and stay and take on the opportunities to progress" (Usdaw official). The increase in the real national minimum wage therefore had an indirect effect, speeding up this objective by impacting on the pay offered by competitors. ${ }^{14}$

An important result of this strategy was the elimination of the two bottom grades in Tesco's pay structure, contributing to an immediate one-off uprating of the pay of the lowest paid Tesco employees. The lowest grade, Grade A (trolley staff), was abolished in 2001 and all Grade A workers upgraded to Grade B. Then, in years 2002, 2003, 2004 and 2005 Tesco and Usdaw committed to a gradual diminishing of the gap between Grade B and Grade C pay rates by awarding additional increases to the Grade B rate. ${ }^{15}$ By 2005, the rates were equivalent and Grade $\mathrm{B}$ was abolished. The changes in rates during 1999-2008 are shown in Table 14.7 (no data available for Grade A rates). This strategy uprated the pay and grades of around 98,000 employees - approximately one-third of the Tesco workforce. Both Usdaw and Tesco agreed this was a sensible approach to offering more attractive, competitive rates of pay. Moreover, changes in work organization (especially multi-skilling) made it impossible to justify pay differences between Grade B and C staff.

While Usdaw does not have an explicit bargaining strategy related to the gap between pay rates and the national minimum wage, nevertheless it monitors the gap closely. In the words of one of the officials interviewed, "We've tried to maintain a $£ 1$ differential. This is not explicit Usdaw policy. But just to give us a rough idea, something to aim for." Abolishing the bottom two

14. At the same time, other changes in work organization involving multi-skilling of low-grade sales assistants and shelf-fillers strengthened Usdaw's argument.

15. For example, in 2002 the core award was 2.7 per cent, but Grade B rates were increased by 4.1 per cent, and in 2003 the core award was 2.9 per cent and Grade B increased by 3.3 per cent. 
Table 14.7 Lowest pay rates for Tesco adult staff and the gap with the national minimum wage, United Kingdom, 1999-2008

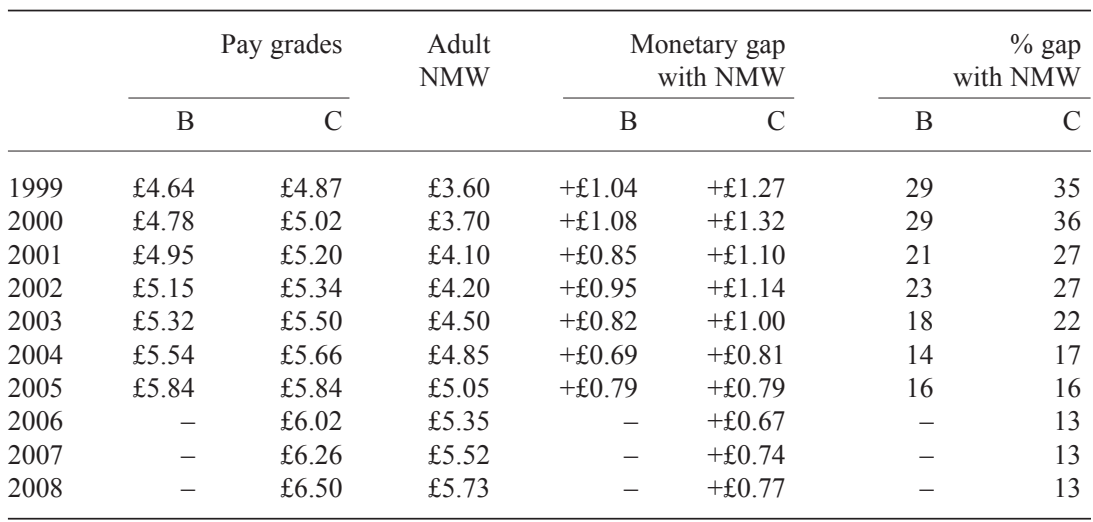

Note: Pay rates apply to persons 18 years and older with at least 12 months' service and exclude location allowances; NMW, national minimum wage.

Source: Information supplied by Usdaw officials.

grades, A and B, was intended to widen the pay gap with the national minimum wage. However, Table 14.7 shows that in 2005, when both grades had been abolished and the lowest paid workers were paid a Grade $\mathrm{C}$ rate, the gap was just 79 pence, considerably less than the gap between the lowest pay rate and the national minimum wage in 1999 and 2000 when it exceeded $£ 1$. Furthermore, there is no evidence of union success in widening the gap between the Grade $\mathrm{C}$ pay rate and the national minimum wage since 2005. An alternative and better measure of the gap is the percentage difference between the national minimum wage and the lowest rate of pay. This has narrowed substantially from 29 per cent in 1999 (with respect to Grade B) to just 13 per cent in 2008 (with respect to Grade C). The pay trends thus suggest that Tesco, not Usdaw, has enjoyed the upper hand in pay bargaining.

On the one hand, therefore, the national minimum wage has had an indirect effect in enabling Usdaw to negotiate the removal of the bottom two pay grades. On the other hand, it has not provided a lever for Usdaw to maintain the differential between Tesco's low-paid staff and the national minimum wage. The picture is one of compression of pay rates among the lower paid staff, with an initial boost at the bottom followed by a gradual shift to the left of the pay distribution.

Against this basic backdrop of change, there have been additional pay reforms that complicate the resulting picture. First, a new higher pay grade for 
"Team Leader" was introduced in 2005 in an effort both to fill holes in what had, during the 1990s, become a delayered internal job ladder and also to establish more promotion opportunities. The effect was to replace a pay scale that ranged from Grades B-F in 2004 with one that ranged from $\mathrm{C}-\mathrm{F}$ with an additional Team Leader Grade (plus a supplement for bakery production). The new team leader grade partially offsets the compression in pay caused by abolishing the two lowest grades. Also, the new post enhances job quality of sales assistants at Tesco since, according to the Usdaw official interviewed, it not only establishes a new, higher paid job post in the usual internal career ladder but also acts as a bridge to further promotion to line manager posts.

Second, Tesco adds location allowances to pay rates in approximately onethird of its stores, the bulk of which are in the South-East of England. Four bands apply, varying from an additional 3 pence per hour to an additional $£ 1.01$ per hour. For employees at the 36 stores with the highest location allowance, the result is a minimum collectively agreed pay rate of $£ 7.51$, a gap of $£ 1.78$ with the adult national minimum wage, or 31 per cent. And for those working at the 243 stores with the second highest allowance of 68 pence, the percentage gap with the adult national minimum wage is 25 per cent. So for workers at one-third of Tesco stores, the picture looks considerably more positive in terms of their wage differentiation with the national minimum wage. The pay policy also chimes with calls by some of the larger trade unions for a differential national minimum wage for London (Table 14.6 above).

If Tesco workers are segmented by age, then the situation also looks considerably more positive for young workers - for two reasons. First, Tesco adult rates apply to workers aged 18 and over, whereas the national minimum wage adult rate applies to persons aged 22 and over. Second, Tesco applies a youth rate to persons aged under 18 and this is significantly higher than the corresponding national minimum wage, largely because Tesco determines its youth rate as a fixed percentage of the adult rate of pay (83.5 per cent in 2008).

Table 14.8 details the gaps with the respective national minimum wage rates for Tesco employees on the lowest grade aged 18-21 and aged 16-17. It is clear that young people working at Tesco enjoy a considerable pay premium compared to the corresponding national minimum wage: more than 50 per cent for 16-17-year-olds and 36 per cent for 18-21-year-olds in 2008. The large difference explains why Usdaw argues for abolition of the 18-21 national minimum wage since it has no practical relevance for the Tesco workforce.

\section{Unison and the National Health Service "Agenda for Change"}

While Usdaw has not explicitly sought to address the issue of low pay in the course of its pay negotiations, Unison, in its negotiations with the NHS, has done so. According to the interviewed senior Unison official, the national min- 
Table 14.8 Tesco youth pay rates and the gap with the corresponding national minimum wage, United Kingdom, 2000-08

\begin{tabular}{|c|c|c|c|c|c|c|c|c|}
\hline & \multicolumn{4}{|c|}{ Employees aged 16-17 } & \multicolumn{4}{|c|}{ Employees aged 18-21 } \\
\hline & Pay & NMW & Gap & $\%$ Gap & Pay & NMW & Gap & $\%$ Gap \\
\hline 2000 & $£ 4.14$ & - & - & - & $£ 4.78$ & $£ 3.20$ & $£ 1.58$ & 49 \\
\hline 2001 & $£ 4.29$ & - & - & - & $£ 4.95$ & $£ 3.50$ & $£ 1.45$ & 41 \\
\hline 2002 & $£ 4.41$ & - & - & - & $£ 5.15$ & $£ 3.60$ & $£ 1.55$ & 43 \\
\hline 2003 & $£ 4.54$ & - & - & - & $£ 5.32$ & $£ 3.80$ & $£ 1.52$ & 40 \\
\hline 2004 & $£ 4.67$ & $£ 3.00$ & $+£ 1.67$ & 56 & $£ 5.54$ & $£ 4.10$ & $£ 1.44$ & 35 \\
\hline 2005 & $£ 4.88$ & $£ 3.00$ & $+£ 1.88$ & 63 & $£ 5.84$ & $£ 4.25$ & $£ 1.59$ & 37 \\
\hline 2006 & $£ 5.02$ & $£ 3.30$ & $+£ 1.72$ & 52 & $£ 6.02$ & $£ 4.45$ & $£ 1.57$ & 35 \\
\hline 2007 & $£ 5.23$ & $£ 3.40$ & $+£ 1.83$ & 54 & $£ 6.26$ & $£ 4.60$ & $£ 1.66$ & 36 \\
\hline 2008 & $£ 5.42$ & $£ 3.53$ & $+£ 1.89$ & 54 & $£ 6.50$ & $£ 4.77$ & $£ 1.73$ & 36 \\
\hline
\end{tabular}

Note: Pay rates are the lowest rates for the particular year that applies to a Tesco employee with at least 12 months' service and exclude location allowances; NMW, national minimum wage.

Source: Information supplied by Usdaw officials.

imum wage has "undoubtedly" had a positive role in bolstering its strategy on low pay. It has allowed the union to negotiate at a level above a rising wage floor and has also improved the position of outsourced workers delivering services to public sector hospitals.

In the context of a rising real national minimum wage, Unison has won relatively substantial improvements for low-wage workers in the NHS. A key uplift was secured with the signing of a new pay structure, known as "Agenda for Change", effective since April 2004. Table 14.9 lists the bottom pay rates for ancillary services workers (cleaners, caterers, and so on) since 1999 and tracks the nominal and percentage gap with the adult national minimum wage.

The adoption of the new "Agenda for Change" pay structure in 2004 had a substantial impact on improving low pay and establishing a significant differential with the national minimum wage. During 1999-2003, the gap with the national minimum wage varied between just 2 and 8 per cent. In 2004, the gap widened to 18 per cent, owing to a substantial increase in the lowest rate of pay - from $£ 4.61$ in April 2003 to $£ 5.71$ in April 2004, a rise of 24 per cent.

Subsequent to the successful targeting of low wages in its negotiation of "Agenda for Change", in 2005 Unison adopted three low-pay strategies: (i) to apply flat-rate pay increases for low-pay bands; (ii) to abolish the lowest pay band; and (iii) to raise the lowest rate to $£ 6.75$. The broader context of the national minimum wage was important. Specifically, Unison's approach 
emerged during the course of the period when the Low Pay Commission had explicitly adopted a policy of improving the national minimum wage relative to average earnings. Unison's proactive support of the national minimum wage ${ }^{16}$ arguably encouraged it to pursue progressive pay strategies that built on the foundations of a rising national minimum wage. It applied the first strategy effectively during a staged deal negotiated in 2007 (in a context of threatened industrial action). A 2.5 per cent pay rise was agreed for staff paid at the higher pay points, 19-56. But, for the lowest paid staff, Unison negotiated a special flat annual sum of $£ 400$ for those on pay points $1-7$ and a pay deal of 2.5 per cent plus the flat sum of $£ 38$ for workers on pay points $8-18$. For the lowest paid full-time workers the deal meant an annual salary of $£ 12,182$ rather than $£ 12,077$, had the formula of 2.5 per cent been applied. While clearly significant in terms of the annual salary, it has not prevented the gradual diminishing of the gap with the national minimum wage. Table 14.9 shows that in 2008, the lowest rate of pay in the NHS was just 10 per cent higher than the adult national minimum wage. Nevertheless, further progress ought to follow from the three-year pay settlement for 2009-11, since Unison has proposed that years 2 and 3 should involve additional increases for the low-paid. However, details are not yet available and, at the time of the interviews, several unions had voted to reject the agreement because of concern that additional monies for low-wage workers might reduce the core award (interview with Unison official).

Unison's second strategy, to abolish the lowest pay band - thereby extending the job ladder and improving skill development opportunities for lowwage workers - has also met with partial success to date. Until 2008, the bottom two pay bands overlapped significantly. Band 1 pay rates (for example, for cleaners) stretched from pay points 1 to 4 ( $£ 6.30$ to $£ 6.98$ per hour), and Band 2 pay rates (for example, cleaner supervisors) ranged from pay points 2 to 9 ( $£ 6.63$ to $£ 8.18$ per hour). According to the interviewed Unison official, the 2009 pay deal includes the elimination of the first pay point, so that entry to Bands 1 and 2 will be at an equivalent rate of pay. Unison's next move is possibly to seek to merge the two bands (effectively abolishing Band 1), thereby stretching the job ladder for all staff, previously confined to just four pay points. A "skill gateway" at the fourth pay point may be negotiated in order to encourage a practice of skill development with pay promotion. This strategy thus promises to enhance job quality considerably for the lowest paid NHS workers.

16. It is worth noting that Unison's links with the LPC have been strong, including direct representation as LPC members: Rita Donaghy (1998-1999, member of Unison Executive Council) and Heather Wakefield (2006-, National Secretary for Unison's Local Government Service Group) 
Table 14.9 Evolution of lowest pay rates among NHS ancillary services staff and the gap with the national minimum wage, United Kingdom, 1999-2008

\begin{tabular}{|c|c|c|c|c|c|}
\hline & \multicolumn{2}{|c|}{$\begin{array}{l}\text { Lowest hourly rate of } \\
\text { pay, ancillary staff: }\end{array}$} & \multirow[b]{2}{*}{ Adult NMW } & \multirow[b]{2}{*}{$\begin{array}{l}\text { Monetary gap } \\
\text { with NMW }\end{array}$} & \multirow[b]{2}{*}{$\begin{array}{c}\% \text { gap } \\
\text { with NMW }\end{array}$} \\
\hline & $\begin{array}{l}\text { (Former) } \\
\text { Whitley } \\
\text { Council }\end{array}$ & $\begin{array}{l}\text { (New) Agenda } \\
\text { for Change }\end{array}$ & & & \\
\hline 1999 & $£ 3.86$ & - & $£ 3.60$ & $+£ 0.26$ & 7 \\
\hline 2000 & $£ 4.01$ & - & $£ 3.70$ & $+£ 0.31$ & 8 \\
\hline 2001 & $£ 4.20$ & - & $£ 4.10$ & $+£ 0.10$ & 2 \\
\hline 2002 & $£ 4.47$ & - & $£ 4.20$ & $+£ 0.27$ & 6 \\
\hline 2003 & $£ 4.61$ & - & $£ 4.50$ & $+£ 0.11$ & 2 \\
\hline 2004 & $(£ 4.76)$ & $£ 5.71$ & $£ 4.85$ & $(-£ 0.09)+£ 0.86$ & 18 \\
\hline 2005 & $(£ 4.92)$ & $£ 5.89$ & $£ 5.05$ & $(-£ 0.13)+£ 0.84$ & 17 \\
\hline 2006 & - & $£ 6.04$ & $£ 5.35$ & $+£ 0.69$ & 13 \\
\hline 2007 & - & $£ 6.13$ & $£ 5.52$ & $+£ 0.61$ & 11 \\
\hline 2008 & - & $£ 6.30$ & $£ 5.73$ & $+£ 0.57$ & 10 \\
\hline
\end{tabular}

Note: Pay rates apply from 1 April each year. National minimum wage rates apply from October each year (with the exception of the first national minimum wage on 1 April 1999). The table compares the April pay rate with the October national minimum wage of the same year; NMW, national minimum wage.

Source: Historical Whitley Council rates are stored as "Advanced Letters" on the Department of Health website, www.dh.gov.uk/en/Publicationsandstatistics/ (accessed June 2008). Agenda for Change rates are available as "Pay Circulars" on the NHS Employers' website, www.nhsemployers.org/pay-conditions (accessed June 2008).

Overall, both cases illustrate a relatively positive influence of a rising national minimum wage on the ability of trade unions to negotiate better pay for the low-paid and, importantly, to enhance job quality by improving internal job ladders. The two cases demonstrate the value of different trade union strategies - indirect and direct targeting of the low-paid - and highlight the importance of the national minimum wage as a benchmark for evaluating success in differentiating the relative position of low rates in jointly agreed pay structures. Nevertheless, both cases also shed light on the limits to the unions' wage bargaining position. Usdaw has witnessed a gradual diminishing of the gap with the national minimum wage, down to 13 per cent in 2008 , despite important advantages being maintained for young workers and those in hardto-recruit areas. And Unison enjoyed a boost in the gap in 2004, but a shrinkage since then, down to just 10 per cent in 2008. No details have been offered here about premium payments for unsocial and overtime hours, but it is worth noting that such conditions are significantly more generous for NHS workers than for Tesco workers. 


\subsection{CONCLUSIONS}

The UK experience of introducing a new statutory national minimum wage demonstrates that this can be achieved without facing a trade-off between wage equality and labour market efficiency. In the eight years since the 1999 introduction of the national minimum wage, workers have experienced neither a heightened risk of unemployment nor reduced job opportunities. Moreover, real wage growth has not been diminished by inflationary pressures, since firms have not responded to the national minimum wage by raising product prices. It is quite possible, viewing the situation from the vantage point of 2008, when many EU economies are experiencing slowdowns in economic growth, that the UK Government was extraordinarily fortunate in its timing and enjoyed a very favourable context of relatively stable trends in job growth, low unemployment and above-average economic growth. It was, perhaps, this generally positive economic outlook that also helped to forge something close to a consensus of expectations among trade unions, employers and Government, which was an important backdrop to the development of the LPC as a well-functioning, tripartite body, capable of reviewing and regulating the minimum wage. Conducting the same policy experiment in today's economic context would be more likely to generate conflicting expectations among social actors, with the possibility of different labour market consequences.

While the United Kingdom's minimum wage has proven to be fully consistent with conventional measures of labour market efficiency, it has only partially delivered on its promise of labour market equality. The share of workers in low-paid jobs has certainly diminished since 1999, most notably during 2003-06 when the LPC explicitly sought to raise the national minimum wage relative to average earnings. And such improvements have been especially beneficial for women for whom the share of low-wage work dropped from 45 per cent to 36 per cent during 1999-2007, contributing to a narrowing of the gender pay gap in recent years. However, it is arguable that the national minimum wage has not done enough to radically reshape the wage structure in the United Kingdom. In a context where workplaces benefit from skill-enhancing technologies, where many low-skill jobs are offshored and where labour market entrants have higher levels of education, one might expect a national minimum wage to effect a more significant transformation in the wage distribution. Ultimately, the share of low-wage work remains high by international standards and it may be appropriate for the LPC to investigate what role the national minimum wage ought to play, along with complementary institutions and supporting employer pay and employment practices, in reducing the share of low-wage jobs in the UK economy.

This chapter contributes new empirical evidence to the debate about the 
role played by a statutory minimum wage in processes of collective bargaining. With regard to its effect on the crowding out of the trade unions' role in wage determination, the analysis presented here suggests that this has not occurred. Where it has played an interesting, positive role is with regard to the shaping of unions' strategies towards pay bargaining. Evidence from two case studies suggests that the statutory minimum wage is an important factor in enabling unions to negotiate an upgrading of pay scales at the bottom. Unions deployed varied strategies, including monitoring the gap between the lowest pay rate and the national minimum wage, eliminating bottom rates and introducing new higher paid job posts - both to prevent compression of pay at a level only marginally above the minimum and to enhance job quality by extending career ladders. Such cases are clearly not representative of most UK workplaces, given the generally weak union representation and low levels of collective bargaining coverage. Nevertheless, they provide valuable insight into the positive development of collective bargaining in a new context of a statutory wage floor.

\section{REFERENCES}

Arulampalam, W., A.L. Booth and M.L. Bryan. 2002. "Work-related training and the new national minimum wage in Britain", mimeo, Institute for Social and Economic Research, University of Essex.

Bain, G. 1999. "The national minimum wage: further reflections", Employee Relations, 21 (1): 15-28.

Bazen, S. 2000. "The impact of wage regulation on inequality and labour market flexibility: a comparative approach", Oxford Review of Economic Policy, 16 (1).

Blackburn, S. 1988. "The problem of riches: From trade boards to a national minimum wage”, Industrial Relations Journal, 19 (2): 124-38.

Brewer, M., A. Goodman, A. Muriel and L. Sibieta. 2007. "Poverty and inequality in the UK, 2007", Institute for Fiscal Studies, IFS Briefing Note No. 53.

Brosnan, P. 2003. "The political economy of the minimum wage", in B. Burchell, S. Deakin, J. Michie and J. Rubery (eds), Systems of production, London: Routledge.

Brown, W., P. Marginson and J. Walsh. 2003. "The management of pay as the influence of collective bargaining diminishes", in P. Edwards (ed.), Industrial relations: Theory and practice, Oxford: Blackwell.

Bullock, A., A. Hughes and F. Wilkinson. 2001. The impact of the national minimum wage on small and medium sized businesses in the cleaning and security sectors, report prepared for the Low Pay Commission, ESRC Centre for Business Research, University of Cambridge.

Card, D., and A. Krueger. 1995. Myth and measurement: The new economics of the minimum wage, Princeton, NJ: Princeton University Press.

Cooke, G., and K. Lawton. 2008. "Working out of poverty: A study of the low-paid and the 'working poor'", Institute for Public Policy Research (home page at www.ippr.co.uk, accessed June 2009). 
Denvir, A., and G. Loukas. 2007. "The impact of the national minimum wage: Pay differentials and workplace change", prepared for the Low Pay Commission by the Institute for Employment Studies. Available at: http://www.lowpay.gov.uk/lowpay/research/pdf/ 0394 lpc_final layout.pdf [accessed June 2009].

Dickens, R., and A. Manning. 2003. "Minimum wage, minimum impact", in R. Dickens, P. Gregg and J. Wadsworth (eds), The labour market under New Labour: The state of working Britain, London: Palgrave Macmillan.

Dickerson, A. 2007. "Longer term implications of the NMW: A re-examination of employer-provided training", research report for the Low Pay Commission.

DTI (Department for Trade and Industry). 2006. "national minimum wage regulatory impact assessment”. Available at http://www.berr.gov.uk/files/file30361.pdf [accessed June 2009].

Forth, J., and M. O'Mahoney. 2003. "The impact of the national minimum wage on labour productivity and unit labour costs", Research Report for the Low Pay Commission.

Gilpin, N., M. Henty, S. Lemos, J. Portes and C. Bullen. 2006. "The impact of free movement of workers from Central and Eastern Europe on the UK labour market", report for the Department for Work and Pensions.

Grainger, H., and M. Crowther. 2007. "Trade union membership 2006”, Employment Market Analysis and Research, Department of Trade and Industry.

Grimshaw, D. 2004. "British living wage and low wage campaigns", in D. Figart (ed.), Living wage movements: Global perspectives, New York: Routledge.

Grimshaw, D., and M. Carroll. 2006. "Adjusting to the national minimum wage: Constraints and incentives to change in six low paying sectors", Industrial Relations Journal, 37 (1): 22-47.

Heyes, J., and A. Gray. 2003. "The implications of the national minimum wage for training in small firms", Human Resource Management Journal, 13 (2): 76-86.

Hiizen, A. 2007. "OECD workers in the global economy: increasingly vulnerable?", BERR conference on globalisation and the labour market, London.

IDS. 2004. Report to the Low Pay Commission on the Impact of the national minimum wage in 2003 and 2004 (September).

Kohl, H., and H.-W. Platzer. 2007. "The role of the state in Central and Eastern European industrial relations: the case of minimum wages", Industrial Relations Journal, 38 (6): 614-35.

Lemos, S., and J. Portes. 2008. "The impact of migration from the new EU member states on native workers", report for the Department for Work and Pensions.

Lewis. 2008. "P. Daffodil harvester stripped of gangmaster licence and accused of using forced labour", The Guardian, 8 May 2008.

Low Pay Commission (LPC). 1998. The national minimum wage: First report of the Low Pay Commission, Cmnd 3976, London: HMSO.

Low Pay Commission (LPC). 2003. The national minimum wage: Building on success, Fourth report of the Low Pay Commission, Cmnd 5768, London: HMSO.

LSC (Learning and Skills Council). 2007. "Migrant workers and the labour market". Available at http://readingroom.lsc.gov.uk/lsc/National/nat-migrantworkersandthelabourmarket.pdf [accessed June 2009].

Machin, S., and J. Wilson. 2004. "Minimum wages in a low wage labour market: Care homes in the UK", The Economic Journal, 114 (March): C102-C109. 
Mason, G., K. Mayhew and M. Osborne. 2008. "Low-paid work in the UK: an overview", in C. Lloyd, G. Mason and K. Mayhew (eds), Low wage work in the $U K$, New York: Russell Sage Foundation.

Miller, L., J. Hurstfield and N. Stratton. 2002. "The national minimum wage and employers' training decisions", research report for the Low Pay Commission.

OECD. 2007. OECD Economic Outlook, Volume 2007, Issue 1, OECD Publishing.

Ram, M., P. Edwards, M. Gilman and J. Arrowsmith. 2001. "The dynamics of informality: employment relations in small firms and the effects of regulatory change", Work, Employment and Society, 15 (4): 845-73.

Stewart, M. 2002. "Estimating the impact of the Minimum Wage using geographical wage variation", Oxford Bulletin of Economics and Statistics, 64: 583-605.

Stewart, M. 2004. "The employment effects of the national minimum wage", Economic Journal, 114 (March): C110-C116.

Sutherland, H. 2001. "The national minimum wage and in-work poverty", University of Cambridge, DAE Working Papers Number MU0102. Available at: www.econ.cam. ac.uk/dae/mu/publications/mu0102.pdf [accessed June 2009]. 